\title{
A CRITICAL ASSESSMENT OF THE PERCEPTIONS OF POTENTIAL GRADUATES REGARDING THEIR GENERIC SKILLS LEVEL: AN EXPLORATORY STUDY
}

\author{
EE Smith and J Krüger
}

Department of Business Management, Nelson Mandela Metropolitan University

\begin{abstract}
This article outlines the perceptions of potential Business Management graduates regarding their generic skills level. To achieve the aim of this article, a literature study and empirical research were undertaken. A self-administered questionnaire was distributed to 205 potential Business Management graduates at a tertiary institution. To investigate the relationship between the independent and dependent variables, thirteen null-hypotheses were tested. The results revealed some significant relationships between these variables. Seven predetermined generic skills factors, namely basic, communication, management, environmental awareness, intellectual, self and career management as well as interpersonal skills, were identified and empirically tested in this article. Skills development should take place within an overall framework providing for the coordination and progression of skills development from first to final year of study. Future curricula development should specifically focus on developing those skills lacking most in potential graduates as identified in this article.
\end{abstract}

JEL D83, 84, J24

\section{1}

\section{Introduction}

The results in this article concern the nature and level of generic skills acquired by potential Business Management graduates at a higher education institution. Although Kaijage (2006: 3) argues that a vast amount of research has been accumulated, investigating the relationship between higher education and the job market, Holmes (2000: 1) is of the opinion that there is a need for reframing the skills agenda. The current understanding of the relationship between higher education and the occupational order is framed mainly in terms of "transferable skills". Such skills are more generic in nature (rather than specific to any particular subjectdiscipline or occupation). Kings College London (2006: 1 ) concurs that there is more to a degree than simply applying it - one has to acquire a range of very specific skills as well as generic transferable skills, which could form the basis for any career. The focus of this study is, however, on generic skills. As education and training do not come to a halt at the end of the academic career, there should be a continuous development and refinement of transferable skills.

Maher and Nield (2005: 1) maintain that in an increasingly competitive and volatile graduate employment market, it is vital for students to be equipped with skills that will enable them to maximise their potential for a successful career. McNair (2003: 1) concurs that "successful graduates will need to have greater ownership of their employability skills and the confidence to cope with economic upheavals in order to identify and capitalise on career opportunities over a lifetime." According to Hillage and Pollard (1998: 2) employability is about much more than the acquisition of a first job and actually relates to the actions that enhance the student's capability to operate self-sufficiently within the labour market. The Queensland University of Technology (2005: 1) maintains that 
employers need to be convinced that graduates are going to demonstrate employment-related skills as well as disciplinary expertise, while at the same time feeling confident in their understanding and articulation of their capacity development and preparedness for a challenging and dynamic future. Earl (2006: 1) indicates a clear discrepancy between the expectations of employers and those of graduates regarding the skills needed for employment. Although it is not the focus of this article, a gap has been identified between the skills levels of graduate job seekers and those expected by employers. Graduates therefore need to consider alternative means of gaining the skills necessary for their chosen career, particularly as few companies provide graduate training programmes. The University of Hertfordshire (2005: 1) has said that methods of making skills explicit in individual parts of the curricula and integrating them with academic content may bring about some skills development. However, their full potential can be realised only when they are used within an overall framework providing for the coordination and progression of skills development from the point of entry to the education system until exit.

\section{2}

\section{Objectives}

The primary objective of this article is to investigate the perceptions by potential Business Management graduates regarding their generic skills levels. To achieve this main objective, the following secondary objectives are identified:

- To highlight the nature of the generic skills of potential graduates.

- To analyse the factors influencing generic skills levels of graduates.

- To investigate empirically the generic skills level of potential Business Management graduates.

- To provide a generic skills inventory checklist for curriculum developers in designing study material.

- To provide general guidelines for developing generic skills among graduates.
3

\section{Generic skills: A theoretical overview}

According to Woodbury University (2006: 1 ) the pace of change makes it impossible to imagine that the skills required in the workplace will remain the same in the $21^{\text {st }}$ century. The most significant challenge for graduates will be to manage the relationship between work and learning. A wide range of stakeholders are involved in developing these generic skills: students, higher education, employers and policy makers. Besides being skilled in their disciplines and possessing current disciplinary knowledge and up-to-date technical skills, today's graduates also need generic skills. Numerous studies have pointed to a set of "transferable skills or competencies" required of graduates by employers (UCE, 2006: 2). Forster (2006: 2 ) is of the opinion that all higher education institutions, employers and other interested parties should identify a set of valued generic skills that could be effectively assessed at university entry and exit level. Frame and Canter (2001: 10) and Chartered Management Institute (2006: 4) provide the following guidelines for the acquisition of generic skills by graduates:

- Greater contribution from career advisory services within universities in raising graduates' preparedness for the world of work.

- Direct provision should be made for all students to experience a minimum amount of training in generic workplace skills which should be taught by someone outside the students' academic faculty.

- To improve the links between industry and education, both sectors should consider developing more programmes to enable the part-time or temporary transfer of staff between industry and higher education.

- Design of new university programmes must be guided by focussing on graduate skills as required by industry.

\subsection{Concept clarification}

WordNet (2006: 1) defines a skill as an ability acquired by training. Robbins and DeCenzo 
(2004: 20) concur that a skill is "the mental ability to demonstrate a system and sequence of behaviour that is functionally related to attaining a performance goal." It thus embraces a range of desirable behaviours, attitudes and personal characteristics. Eironline (2006: 1) further argues that it is apparent that "skill" now has a broader meaning than in the past, when it tended to be equated with the manual dexterity and technical know-how of the craftworker, scientist or technician. In fact the definition of "skill" has undergone an enormous transformation over the past two decades. This article is, however, concerned with the generic or core skills needed by graduates if they are to be effective members of a flexible, adaptable, dynamic and competitive workforce. National Centre for Vocational Education Research (2003: 1) regards generic skills as those that apply across a variety of jobs and life contexts and offers a theoretical or academic and practical approach to defining generic skills. These skills are also known as key skills, key competencies, transferable skills and employability skills. It thus appears that generic skills relate to both employment and social life. Arcioni (1997: 1) contends that generic skills could be placed into three contexts: general tertiary education, the workplace and a degree. The integration of generic skills has to be recognised as a challenge for all involved - a change in attitude and the way subjects are taught.

\subsection{Factors influencing graduate generic skills development}

According to Kelly (2006: 4) graduate employers operate within business environments of increasing competition and are thus more demanding than in the past when it comes to new graduates' skills. Crebert (2006: 1) further highlights the fact that graduate skills have become increasingly important over the last decade as graduates enter a workplace that is more flexible, insecure and technologydependent than ever before. Table 1 provides an outline of the most important factors influencing graduate generic skills development.

Table 1

Factors influencing graduate generic skills development

\begin{tabular}{|l|l|}
\hline External trends and developments & Internal factors \\
\hline Strong competition & Changes in people-management policies \\
\hline Large, diverse graduate supply from higher education & $\begin{array}{l}\text { Renewed interest in developing leadership skills in } \\
\text { graduates }\end{array}$ \\
\hline $\begin{array}{l}\text { A “consumerism" attitude of graduate's views about } \\
\text { job/careers }\end{array}$ & $\begin{array}{l}\text { Less career hierarchical structures and more self- } \\
\text { managed careers }\end{array}$ \\
\hline Improvements in graduate employability & Changing career philosophies \\
\hline $\begin{array}{l}\text { Employer concerns about the quality of higher } \\
\text { education output }\end{array}$ & $\begin{array}{l}\text { Structural and organisational changes (e.g. } \\
\text { globalisation and new technology) }\end{array}$ \\
\hline $\begin{array}{l}\text { Greater use of information technology in recruitment } \\
\text { processes }\end{array}$ & $\begin{array}{l}\text { Changes in way learning is viewed and encouraged in } \\
\text { organisations }\end{array}$ \\
\hline
\end{tabular}

Source: Adapted from Connor, Hirsch and Barber (2003: 1)

These factors have a significant impact on the extent to and manner in which graduate's develop their generic skills before entering the workplace and then during their career paths. Many other factors, such as demographic characteristics of respondents (e.g. age and gender) could also influence graduate generic skills development.
Various researchers (see for example Crebert, 2006; Green \& Dickerson, 2002 and Goldfinch \& Hughes, 2007) attempted to investigate the influence of demographic variables on acquisition of generic skills. Cliff (2007) argues that, especially in South Africa, factors such as mother tongue language, ethnic group and 
socio-economic status play an important role in skills acquisition and this should be viewed in the context of ongoing research and practical interest. There is an important interplay of personological, educational context and sociocultural factors in developing skills levels but it is not always easy or possible to indicate what demographic differences make a difference (Mannix \& Neale, 2007). Students often enter the higher education system from backgrounds that have not adequately prepared them for participating.

\subsection{Key generic graduate skills}

Graduates need to develop a range of generic skills. Although literature offers various classifications of these generic skills, the following key generic graduate skills are outlined below and empirically investigated in this study: basic; communication; management; environmental awareness; intellectual; self and career management and interpersonal. This classification was developed after an extensive literature search on lists of generic skills. These categories of generic skills should not be seen as exhaustive or watertight compartments, as some skills could fall into more than one category. Specific examples of these categories of skills are indicated in italics below.

\section{- Basic skills}

Basic skills include literacy (ability to read and write) and numeracy (ability to use numbers, to compute or calculate). According to the American Library Association (2006: 1), information literacy refers to the ability to "locate, evaluate, and use needed information effectively." It is also often termed information technology communication literacy. Eisenberg and Johnson (2006: 1) maintain that beyond the basic skills of reading, writing and arithmetic, the citizen-worker of the new millennium needs to be skilled in the technological tools of the Information Age-computer networks, telecommunication systems and databases.

\section{- Communication skills}

Schermerhorn, Hunt and Osborn (1997: 339) define the skill of communicating as the ability to send and receive messages with attached meanings. Robbins and DeCenzo (2004: 262) concur that this skill entails the transference and understanding of meaning. The sender and receiver of messages could do this in oral, written, non-verbal format or by means of an electronic device. This skill is used during negotiations, presentations, giving instructions or resolving conflict.

\section{- Management skills}

Hellriegel, Jackson, Slocum, Staude, Amos, Klopper, Louw and Oosthuizen (2004: 12) regard management skills as competencies, knowledge, behaviours and attitudes that a manager needs in a variety of managerial jobs and organisational settings. Mooney (2002: 2) sees them as the ability to achieve organisational goals in an effective and efficient manner, through planning, organising, controlling and directing organisational resources. Some literature sources (see for example Answers. Com, 2006: 4) equate management and administration as being one and the same, but Mullins (1996: 398) indicates that there appears to be growing acceptance of the term "management" to be the general descriptive label while "administration" relates to the more specific function concerned with the design and implementation of systems and procedures (ability to run an office efficiently). Another important managerial skill is that of decision-making. Nieman and Bennett (2004: 119) refer to this skill as the ability of making a choice between various alternatives in order to select the most appropriate alternative to solve a problem.

\section{- Environmental awareness skills}

According to Bishop, Reid, Stables, Lencastre, Stoer and Soetaert (2000: 268), these skills refer to peoples' ability to become aware of or sensitive to their environment. This could include an awareness of the physical environment or the business environment. Business awareness skills include such things as an appreciation for an organisation's objectives, culture and customers (Graduate Skills Online, 2006: 
1). Other environmental awareness skills include ethical awareness skills (ability to judge behaviour in terms of right and wrong) and social responsibility skills (ability to pursue goals that are good for the society) (Crebert, 2006: 1).

\section{- Intellectual skills}

Marwala (2006) describes intellectual skills as the ability to use scientific means of inquiry to reach conclusions with the use of logic and deduction. Intellectual skills equip the individual with a mindset that allows them to deal decisively with any challenges, irrespective of the scale or the complexity of the problems at hand. SAICA (2006) describes intellectual skills as those skills that enable the individual to solve problems, make decisions and exercise good judgement in complex organisational situations. According to the UK Centre for Legal Education (1998) intellectual skills refer to the ability to analyse, think critically and creatively, evaluate information and disseminate information. The above definitions show that intellectual skills include gathering and analysis of information, problem-solving (identifying and reasoning) and time management (prioritising) (Hellriegel et al., 2004: 15).

\section{- Self and career management skills}

Hellriegel et al. (2004: 21) describe selfmanagement skills as taking responsibility for one's life at work and beyond. It is also important to take responsibility for one's own career development (career management skill). Taking responsibility for one's life and career can take place only if there is an understanding of the type of work that will create satisfaction so that the skills needed for performing the work effectively and efficiently can be developed. Other self-management skills include showing integrity and acting ethically, having personal drive and resilience (doing something no one else has done while facing setbacks and failures), balancing work and life issues and self awareness and development (Hellriegel et al., 2004: 21-22).

\section{- Interpersonal skills}

SAICA (2006) defines interpersonal skills as skills that will enable someone to work with others for the common good of the business receive and transmit information, form reasoned judgements and make effective decisions. Fielding (2003) is of the opinion that if individuals want to improve their interpersonal skills they should be assertive, have clear statements of perceptions and feelings as well as on facts, intentions and actions. According to Gibson, Ivancevich and Donnelly (1997: 212) there can be no understanding and knowledge of problems and decisions to be made without effective communication and constructive conflict. Other interpersonal skills include teamwork, political acumen, networking, risktaking, helpful criticism, objectivity, active listening, giving the benefit of the doubt, support and recognising the interests and achievement of others (Gibson et al., 1997: 212).

\subsection{Hypotheses}

Various null-hypotheses were formulated to investigate the relationship between the independent variables (classification data) and dependent variables (seven generic skills factors of potential Business Management graduates). The null-hypotheses formulated and tested in this article, are the following:

$\mathrm{H} 0_{1}$ The basic skills level of potential graduates does not differ regardless of the tertiary qualification for which they are registered.

$\mathrm{H}_{2}$ The basic skills level of potential graduates does not differ regardless of their prior full-time employment status.

$\mathrm{H}_{3}$ The basic skills level of potential graduates does not differ regardless of their orientation towards upgrading their generic skills level.

$\mathrm{HO}_{4}$ The communication skills level of potential graduates does not differ regardless of their age.

$\mathrm{H}_{5}$ The management skills level of potential graduates does not differ regardless of 
the extent to which potential graduates perceive their tertiary qualification as equipping them with the necessary generic skills.

$\mathrm{H}_{6}$ The intellectual skills level of potential graduates does not differ regardless of the extent to which they perceive their tertiary qualification as equipping them with the necessary generic skills.

$\mathrm{H}_{7}$ The intellectual skills level of potential graduates does not differ regardless of their orientation towards upgrading their generic skills level.

$\mathrm{H}_{8}$ The self- and career management skills level of potential graduates does not differ regardless of the tertiary qualification for which they are registered.

$\mathrm{H}_{9}$ The self- and career management skills level of potential graduates does not differ regardless of the extent to which potential graduates perceive their tertiary qualification as equipping them with the necessary generic skills.

$\mathrm{H} 0_{10}$ The interpersonal skills level of potential graduates does not regardless of the gender of the potential graduate.

$\mathrm{H} 0_{11}$ The interpersonal skills level of potential graduates does not differ regardless of the tertiary qualification they are registered for.

$\mathrm{H} 0_{12}$ The environmental awareness skills level of potential graduates does not differ regardless of the tertiary qualification for which they have registered.

$\mathrm{H} 0_{13}$ The environmental awareness skills level of potential graduates does not differ regardless of the extent to which potential graduates perceive their tertiary qualification equip them with the necessary generic skills.

The alternative hypotheses $\left(\mathrm{H}_{1}\right.$ to $\left.\mathrm{H}_{13}\right)$ can be formulated as the exact opposite of the above null-hypotheses, indicating that there are relationships among the variables. Based on the eight independent variables (classification data) and seven dependent variables (generic skills), a total of 56 hypotheses were originally formulated and tested by means of ANOVA (43 null-hypotheses indicated no relationships between the tested variables). Only the 13 hypotheses indicating significant relationships are outlined above and reported in this article.

\section{4 \\ Research methodology}

This study uses the quantitative research method whereby the emphasis is on the quantification of variables and statistical controls. The approach followed in this research is that of exploration and description.

For the purpose of this research project, the target population consists of registered thirdyear level (final year) Business Management students at the Nelson Mandela Metropolitan University (including the South, Second Avenue and Missionvale campuses). The unit of analysis is therefore individuals (potential graduates) while the point of focus is characteristics. The sampling frame could be specified as a printout of all third year registered Business Management students at the above-mentioned institution. This clearly demarcates the field of study. A random probability sampling technique is used. The total sample size was 435 .

Based on the size of the sample (435) a survey by means of self-administered questionnaires was the most suitable for this project. The variables of the questionnaire were developed according to the literature study and existing international pre-tested questionnaires on generic skills. Although the questionnaire was self-reporting, the respondents were informed that the variables refer to their actual ability to use these skills and not to what they would like it to be. The questionnaire consists of two sections:

- Section A deals with variables concerned with graduates' generic skills. Seven factors are tested, totalling 30 variables. No indication of the seven factors was provided in the questionnaire. The type of ordinal scale used is that of semantic differential scaled-response questions according to a six-point Likert-type scale (ranging from "not at all" to "excellent").

- Section B provides classification data (demographic characteristics) of respondents and contains a nominal scale of measurement, 
using categorical variables. Eight classification data variables were tested. One open ended question was provided.

As the questionnaire had not previously been used, it was distributed to a few students who were about to graduate (convenient sample). The questionnaire was also given to academics in the field of management and statistics. Some problem areas were identified and suggestions for improvement were made to ensure face validity of the questionnaire.

The type of information required (data specification decisions) for this project can be classified as follows:

- research data are numeric, non-verbal and non-overt (questionnaires);

- both secondary and primary data (survey) were collected.

A total of 205 questionnaires were completed by final year Business Management students (out of a possible 435 registered students). They were handed out to the classes concerned during a lecture period and collected afterwards. The effective response rate is 47.13 per cent.
Completed questionnaireswere inspected, edited, coded and data transferred to an Excel spreadsheet. They were analysed by means of the SPSS statistical software package. The techniques used during the data analysis stage of the research project are:

- descriptive statistics (e.g. mean, standard deviation and range);

- frequency distributions (percentages);

- factor analysis (Cronbach's alpha);

- correlation coefficients and analysis of variance.

\section{5}

\section{Results}

\subsection{Descriptive statistics}

Table 2 provides a summary of the descriptive statistics for Section A of the questionnaire (generic skills). It should be noted that a six-point scale was used, namely, not at all (1), poor (2), some (3), average (4), good (5) and excellent (6).

Table 2

A summary of the descriptive statistics for Section A of the questionnaire: Generic skills level

\begin{tabular}{|l|l|c|c|}
\hline \multicolumn{1}{|c|}{\begin{tabular}{c}
\multicolumn{1}{|c|}{ Items/ } \\
Variables
\end{tabular}} & \multicolumn{1}{|c|}{ Mean } & $\begin{array}{c}\text { Standard } \\
\text { deviation }\end{array}$ \\
\hline $1-3$ & Basic skills (A1) & 5.31 & 0.62 \\
\hline $4-6$ & Communication skills (A2) & 4.51 & 0.82 \\
\hline $7-11$ & Intellectual skills (A3) & 4.69 & 1.04 \\
\hline $13-16$ & Interpersonal skills (A4) & 4.69 & 0.79 \\
\hline $12,17-20$ & Self- and career management skills (A5) & 4.81 & 0.69 \\
\hline $21-23$ & Environmental awareness skills (A6) & 4.91 & 0.76 \\
\hline $24-30$ & Management skills (A7) & 4.72 & 0.80 \\
\hline
\end{tabular}

No in-depth discussion is provided on the descriptive statistics of individual variables. Only those factors with significant statistics are reported on. As far as the measure of central tendency (mean values) of these factors is concerned, it appears that most of these values cluster around point four (average) on the instrument scale. Only one of these seven factors (basic skills) scored a mean value of around five (good) on the instrument scale. The lowest mean score (4.51) is indicated by factor two (communication skills) and the highest mean score (5.31) for factor one (basic skills). None of the mean scores lies on the disagreement 
side of the scale (mean score values of less than three), indicating that most of the respondents agree that they possess these generic skills to a certain degree. The standard deviation is used as a measure of dispersion. The basic skills factor (0.62) has the lowest standard deviation, while the intellectual skills factor (1.04) has the highest standard deviation value. It appears that respondents do not vary too much in their responses on these generic skills, except for the intellectual skills factor.

The following section deals with the descriptive statistics of Section B of the questionnaire (classification data). Table 3 provides a graduate profile of the respondents $(n=205)$ of this study.

Table 3

Frequency distribution results: A graduate profile

\begin{tabular}{|c|c|c|}
\hline Characteristic & Category & $(\%)$ \\
\hline Gender & $\begin{array}{l}\text { Male } \\
\text { Female } \\
\text { No response }\end{array}$ & $\begin{array}{r}41 \\
59 \\
0\end{array}$ \\
\hline Age & $\begin{array}{l}19-20 \\
21-22 \\
23-24 \\
\text { Other } \\
\text { No response }\end{array}$ & $\begin{array}{r}13 \\
38 \\
28 \\
20 \\
1\end{array}$ \\
\hline Tertiary qualification & $\begin{array}{l}\text { BA } \\
\text { BCom } \\
\text { BTech } \\
\text { BSc } \\
\text { Diploma } \\
\text { No response }\end{array}$ & $\begin{array}{r}2 \\
76 \\
6 \\
3 \\
10 \\
3\end{array}$ \\
\hline Year of first registration & $\begin{array}{l}2001 \\
2002 \\
2003 \\
2004 \\
\text { Other } \\
\text { No response }\end{array}$ & $\begin{array}{r}10 \\
14 \\
32 \\
39 \\
3 \\
2\end{array}$ \\
\hline Full-time employment status & $\begin{array}{l}\text { Yes } \\
\text { No } \\
\text { No response }\end{array}$ & $\begin{array}{r}18 \\
80 \\
2\end{array}$ \\
\hline Orientation for upgrading skills level & $\begin{array}{l}\text { Take self control } \\
\text { Consider learning } \\
\text { Would learn if required } \\
\text { No need to learn } \\
\text { No response }\end{array}$ & $\begin{array}{r}23 \\
52 \\
14 \\
2 \\
9\end{array}$ \\
\hline $\begin{array}{l}\text { Extent to which graduates believe that tertiary } \\
\text { qualification equip them with necessary skills }\end{array}$ & $\begin{array}{l}\text { Not at all } \\
\text { Poor } \\
\text { Average } \\
\text { Excellent } \\
\text { No response }\end{array}$ & $\begin{array}{r}1 \\
2 \\
23 \\
73 \\
1\end{array}$ \\
\hline
\end{tabular}

It should be noted that the independent variable age was re-categorised for clarity and analysis purposes and is thus not exactly the same as that used in the questionnaire. From Table 3, it is evident that the majority of respondents (59 per cent) are females in the 21-22 category ( 38 per cent). Regarding the tertiary qualification registered for, 156 (76 per cent) of the respondents are registered for a BCom degree, while only 21 (10 per cent) 
respondents indicated their studies were for a diploma. It should be noted that the field of Business Management is only a service module to the faculty of Arts and Science, which explains the low representation of the BA and BSc degrees. The majority of the respondents had registered at the university for the first time in either 2003 (32 per cent) or in 2004 (39 per cent) respectively. It was also found that the minority of respondents (18 per cent) had had previous full-time employment experience, while the vast majority ( 80 per cent) had none. A slight majority (52 per cent) of the respondents indicated that they were willing to obtain additional skills and abilities if this was going to help them to perform their jobs more effectively. Only two per cent ( 2 per cent) felt that they did not need to learn new skills at the present moment. Almost three-quarters ( 73 per cent) of the respondents believed that the tertiary qualification (degree or diploma) they had registered for would equip them with the skills and abilities necessary for the workplace.

\subsection{Frequency distribution results of perceived generic skills lacking}

Further analysis of the generic skills indicates that a number of them as perceived by potential graduates are lacking. For the purpose of this analysis, the responses of the respondents in terms of point one (not at all), two (poor) and three (some) of the six-point Likert-type scale were used as an indication of the respondents' opinions (indicated by the frequencies). The overall frequency of skills lacking for each generic and individual skill are given in Table 4. As some generic skills consisted of more individual skills than others, the average skill lacking for each generic skill was calculated, to allow them to be ranked from those lacking the most to least. Responses to point four (average), five (good) and six (excellent) were excluded from this analysis, as that respondents perceived themselves to possess these skills to a certain extent. Table 4 below summarises those generic skills perceived to be lacking by potential graduates.

\section{Table 4}

Frequency distributions of perceived generic skills lacking

\begin{tabular}{|c|c|c|c|c|}
\hline Generic skills & Individual skills & $\begin{array}{l}\text { Overall } \\
\text { frequency } \\
\text { of skills } \\
\text { lacking }\end{array}$ & Average & Ranking \\
\hline Management skills & $\begin{array}{l}\text { Administration skills (33) } \\
\text { Leading skills (26) } \\
\text { Transferable (21) } \\
\text { Decision making skills (20) } \\
\text { Controlling (18) } \\
\text { Organising (18) } \\
\text { Planning (18) }\end{array}$ & 154 & 22.00 & 3 \\
\hline Intellectual skills & $\begin{array}{l}\text { Information handling skills (27) } \\
\text { Creative thinking skills (26) } \\
\text { Analysing skills (24) } \\
\text { Critical reasoning skills (20) } \\
\text { Problem solving skills (15) }\end{array}$ & 112 & 22.40 & 4 \\
\hline Interpersonal skills & $\begin{array}{l}\text { Political skills (51) } \\
\text { Networking skills (27) } \\
\text { Assertiveness skills (18) } \\
\text { Team working skills (16) }\end{array}$ & 112 & 28.00 & 2 \\
\hline Communication skills & $\begin{array}{l}\text { Conflict resolutions skills (39) } \\
\text { Presentation skills (30) } \\
\text { Negotiation skills (16) }\end{array}$ & 85 & 28.33 & 1 \\
\hline
\end{tabular}




\begin{tabular}{|l|l|c|c|c|}
\hline $\begin{array}{l}\text { Self and career } \\
\text { management skills }\end{array}$ & $\begin{array}{l}\text { Self assessment skills (22) } \\
\text { Flexibility skills (21) } \\
\text { Self promotion skills (18) } \\
\text { Self confidence skills (15) } \\
\text { Development focus skills (9) }\end{array}$ & 85 & 17.00 & 5 \\
\hline $\begin{array}{l}\text { Environmental } \\
\text { awareness skills }\end{array}$ & $\begin{array}{l}\text { Social responsibility (22) } \\
\text { Business awareness skills (14) } \\
\text { Ethical awareness skills (10) }\end{array}$ & 46 & 15.33 & 6 \\
\hline Basic skills & $\begin{array}{l}\text { IT Literacy (15) } \\
\text { Numeracy (3) } \\
\text { Literacy (2) }\end{array}$ & 20 & 6.67 & 7 \\
\hline
\end{tabular}

As can be seen from Table 4, the perceived skills reported by respondents as most lacking are communication (28.33), interpersonal (28.00), management (22.00) and intellectual skills (22.40). The perceived skills least lacking are basic (6.67), environmental awareness (15.33) and self and career management skills (17.00). Further analysis of the individual skills reveals that the skills most lacking by potential graduates are political, conflict resolution, administration and presentation skills (frequencies all above 30). It should be emphasised that all these skills identified as lacking are as respondents perceive them to be.

\subsection{Reliability and validity of the measuring instrument}

External validity refers to the generalisation of research results to other population groups and is ensured by means of a proper sampling procedure and clear guidelines as to the place, time and conditions in which the research was conducted. The internal validity of the instrument's scores is ensured through face validity and content validity. Opinions were obtained from a statistician, as well as experts in the field of academic development, management and graduate placement. To further enhance the internal validity, a pilot study among potential graduates was undertaken. This was done to ensure that the questionnaire items reflect the theoretical content domain of the construct being measured and that it is clear and understandable.

The statistical software package, SPSS, was used to determine the Cronbach's alpha values for the seven predetermined generic skills factors.
The Principle Component Analysis with Direct Oblimin rotation to allow for inter-correlations between the variables constituting each factor was used. To confirm the internal reliability of the seven generic factors, Cronbach's alpha was calculated (refer to Table 5).

To establish the reliability of the various factors, Cronbach's alpha was calculated (indicating internal consistency). The reliability coefficients of Cronbach's alpha for the various factors are above 0.7 , except for basic skills (A1), which are above 0.6 (see Table 5). According to Hair, Anderson, Tatham and Black (1998: 118), Cronbach's alpha value may be decreased to 0.6 in exploratory research. It can therefore be concluded that all factors are internally reliable. The tabled percentage of variance, as presented in Table 5, is the percentage of variance (of the items constituting each factor) explained by each factor. Factor one (basic skills), for example, explains 56.57 per cent of the variance of the three items/variables which constitute this factor. The communication skills factor obtained the highest percentage of variance (66.82 per cent).

\subsection{Correlation}

Regarding the correlation between the variables constituting each factor, an inter-item correlation exercise was conducted. It appears that all of the variables in each factor show strong positive relationships with each other. A positive correlation coefficient ( $r$-value) indicates a strong or positive relationship among the variables. None of the variables showed a negative/reverse relationship. All variables constituting the seven factors indicated strong 
inter-item correlation. The variables with the highest positive $r$-value (strongest positive relationship) were found in the intellectual skills factor (0.6037), while the variable with the lowest positive $r$-value (weakest positive relationship) was found in the management skills factor (0.1038).

\section{Table 5}

Cronbach's alpha for Section A of the questionnaire

\begin{tabular}{|l|l|c|c|}
\hline \multicolumn{1}{|c|}{ Variables } & \multicolumn{1}{|c|}{ Factor } & $\begin{array}{c}\text { Cronbach's } \\
\text { alpha }\end{array}$ & $\begin{array}{c}\% \text { of } \\
\text { Variance }\end{array}$ \\
\hline $1-3$ & Basic skills (A1) & 0.62 & 56.75 \\
\hline $4-6$ & Communication skills (A2) & 0.75 & 66.82 \\
\hline $7-11$ & Intellectual skills (A3) & 0.70 & 47.81 \\
\hline $13-16$ & Interpersonal skills (A4) & 0.72 & 54.11 \\
\hline $12,17-20$ & Self- and career management skills (A5) & 0.75 & 50.23 \\
\hline $21-23$ & Environmental awareness skills (A6) & 0.70 & 61.58 \\
\hline $24-30$ & Management skills (A7) & 0.85 & 58.09 \\
\hline
\end{tabular}

\subsection{ANOVA}

The purpose of this analysis is to investigate the relationship between the independent variables (classification data) and dependent variables (seven generic skills factors) and to test the stated hypotheses. The ANOVA was therefore done on the seven predetermined factors but not on the 30 individual variables as stated in the measuring instrument. Inferential statistics are used to make inferences about the population using sample data and to make decisions about various hypotheses. Figure 1 indicates the possible relationships between the independent and dependent variables. For each of these relationships, 56 hypotheses were formulated, but only those 13 hypotheses indicating significant relationships are reported.

All the significant relationships between the classification variables and generic skills are indicated by these 13 hypotheses. The results of analysis of variance tests of the 13 hypotheses with significant relationships are depicted in Table 6. It appears that demographical or classification variables do not have a substantial influence on the acquisition of generic skills. Other factors (which were not the focus of this study) could however have a more significant influence. 


\section{Figure 1}

Relationships between the dependent and independent variables: Testing of hypotheses

Independent variables

(Classification data)
Dependent variables

(Generic skills factors)

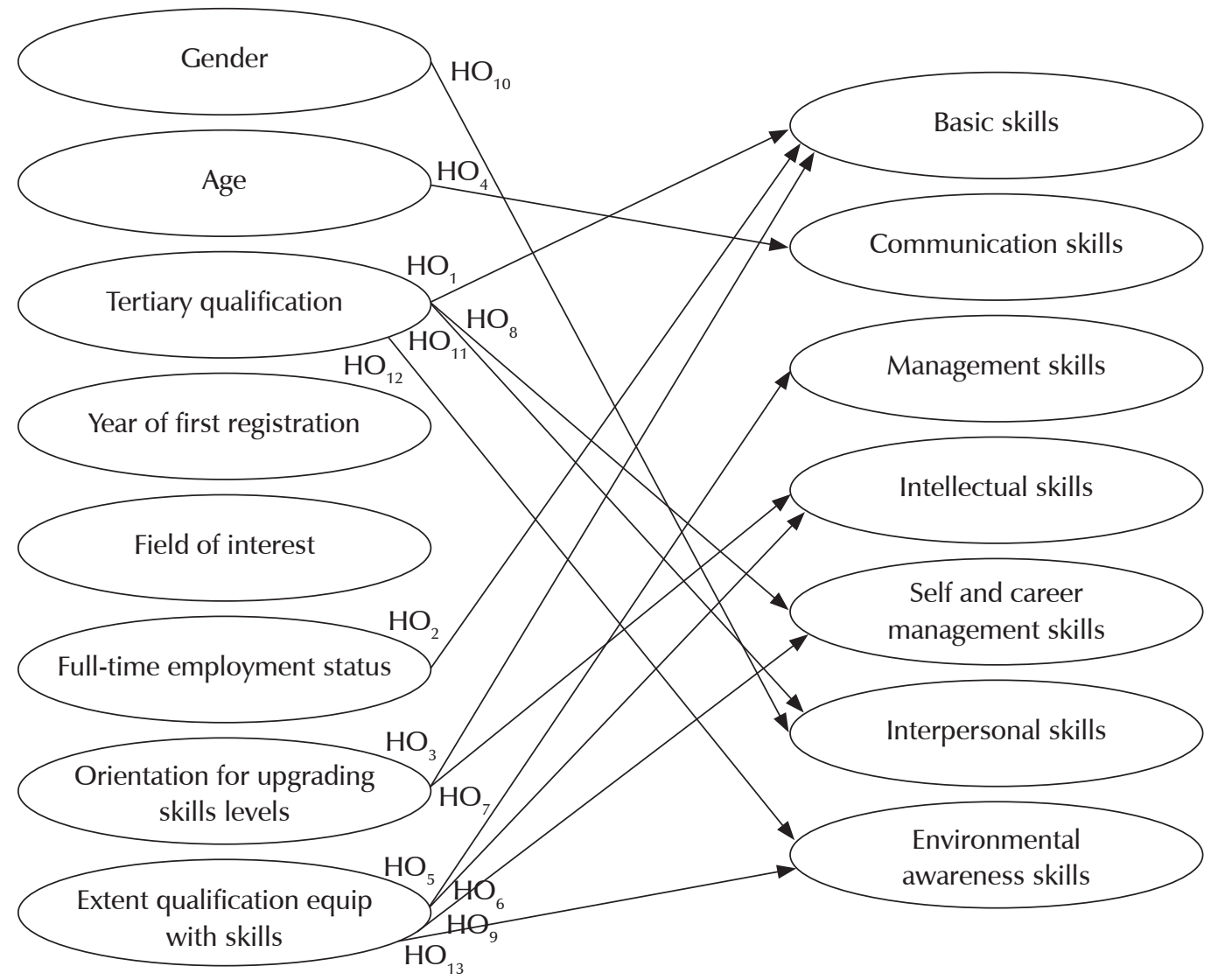

Table 6

Analysis of variance for generic skills and the independent variables (classification data)

\begin{tabular}{|l|l|r|r|r|r|}
\hline \multicolumn{1}{|c|}{ Independent variables } & \multicolumn{1}{|c|}{ Dependent variables } & $\begin{array}{r}\text { Sum of } \\
\text { squares }\end{array}$ & Df & F-test & $\begin{array}{c}\text { P- } \\
\text { value }\end{array}$ \\
\hline Tertiary qualification & Basic skills & 28.423 & 4 & 7.059 & 0.000 \\
\hline Full-time employment status & Basic skills & 9.152 & 1 & 8.430 & 0.004 \\
\hline $\begin{array}{l}\text { Orientation for upgrading skills } \\
\text { level }\end{array}$ & Basic skills & 18.335 & 3 & 6.411 & 0.000 \\
\hline Age & Communication skills & 22.004 & 6 & 3.543 & 0.002 \\
\hline $\begin{array}{l}\text { Extent qualification equip } \\
\text { necessary skills }\end{array}$ & Management skills & 38.115 & 5 & 9.503 & 0.000 \\
\hline $\begin{array}{l}\text { Extent qualification equip } \\
\text { necessary skills }\end{array}$ & Intellectual skills & 33.619 & 5 & 7.608 & 0.000 \\
\hline
\end{tabular}




\begin{tabular}{|l|l|c|c|c|c|}
\hline $\begin{array}{l}\text { Orientation for upgrading skills } \\
\text { level }\end{array}$ & Intellectual skills & 14.096 & 3 & 5.974 & 0.001 \\
\hline Tertiary qualification & $\begin{array}{l}\text { Self and career management } \\
\text { skills }\end{array}$ & 23.344 & 4 & 6.229 & 0.000 \\
\hline $\begin{array}{l}\text { Extent qualification equip } \\
\text { necessary skills }\end{array}$ & $\begin{array}{l}\text { Self and career management } \\
\text { skills }\end{array}$ & 30.125 & 5 & 6.852 & 0.000 \\
\hline Gender & Interpersonal skills & 10.455 & 1 & 9.764 & 0.002 \\
\hline Tertiary qualification & Interpersonal skills & 18.677 & 4 & 4.480 & 0.002 \\
\hline Tertiary qualification & Environmental awareness skills & 14.413 & 4 & 3.923 & 0.004 \\
\hline $\begin{array}{l}\text { Extent qualification equip } \\
\text { necessary skills }\end{array}$ & Environmental awareness skills & 33.194 & 5 & 8.120 & 0.000 \\
\hline
\end{tabular}

The ANOVA results clearly indicate the relationships between the independent variables (classification data) and dependent variables (generic skills). The null hypotheses $\left(\mathrm{H} 0_{1}\right.$ to $\left.\mathrm{H}_{13}\right)$ can, in all cases, be rejected and the research or alternative hypotheses accepted. The other 43 null-hypotheses tested could not be rejected, indicating that there is no significant relationship between the variables tested (these results were not reported in this article). $\mathrm{H}_{1}$ falls within the rejection region $(\mathrm{p}<0.01)$, which indicates that there is a significant relationship between the tertiary qualification registered for and basic skills level of graduates ( $\mathrm{H}_{1}$ accepted). The larger F-statistic of 7.059 and P-value of 0.000 show that there is a highly significant relationship between tertiary qualification registered for and the basic skills level of graduates. The null hypothesis, $\mathrm{H}_{2}$, can also be rejected and the research hypothesis $\left(\mathrm{H}_{2}\right)$ can be accepted, indicating that there is a significant relationship between full-time employment status and basic skills level of graduates (F-statistic 8.430 and $\mathrm{p}<0.05)$. The third null hypothesis $\left(\mathrm{H}_{3}\right)$ is also rejected, based on the F-statistic of 6.411 and P-value of 0.000 . There is a highly significant relationship between orientation towards upgrading skills and basic skills of graduates $\left(\mathrm{H}_{3}\right.$ accepted $)$. Based on the $\mathrm{F}$ statistic of 3.543 and $\mathrm{P}$-value of $0.002, \mathrm{H}_{4}$, can be rejected $(\mathrm{p}<0.05)$. The research hypothesis $\mathrm{H}_{4}$ can be accepted: there is a significant relationship between graduates' age level and their communication skills. $\mathrm{H}_{5}$ can be rejected $(\mathrm{p}<0.01)$ and the research hypothesis $\left(\mathrm{H}_{5}\right)$ can be accepted.

There is a highly significant relationship between the extent to which a tertiary qualification equips graduates with generic skills and their management skills . The P-value of 0.000 and F-statistic of 7.608 reject the null hypothesis $\mathrm{H}_{6}$ and indicate that the extent to which tertiary qualification equips graduates with generic skills differs in terms of their intellectual skills $\left(\mathrm{H}_{6}\right.$ accepted). There also appears to be a highly significant relationship between orientation to upgrading generic skills and the intellectual skills of graduates $\left(\mathrm{H}_{7}\right.$ accepted) $\mathrm{H}_{7}$ can be rejected, based on the F-statistic of 5.974 and $\mathrm{P}$-value of 0.001 . The null hypothesis, $\mathrm{H}_{8}$ is rejected at a significance level of 0.01 (P-value is 0.000 and F-statistic is 6.229). There is a highly significant relationship between the tertiary qualification registered for and self and career management skills of graduates $\left(\mathrm{H}_{8}\right.$ accepted). It also appears that graduates with different perceptions regarding the extent to which their tertiary qualification equips them with the necessary generic skills differ in their acquired levels of self- and career-management. $\mathrm{H}_{9}$ could therefore be rejected $(p<0.01)$ and the research hypothesis $\mathrm{H}_{9}$ could be accepted. $\mathrm{H}_{10}$ can be rejected, based on the F-statistic of 9.764 and P-value of $0.002\left(\mathrm{H}_{10}\right.$ accepted $)$.

There is a significant relationship between the gender of graduates and interpersonal skills level. The null hypothesis $\mathrm{H} 0_{11}$ falls within the rejection region $(\mathrm{p}<0.05)$. The tertiary qualification registered for is related 
to the interpersonal skills level of graduates $\left(\mathrm{H}_{11}\right.$ accepted $) . \mathrm{H}_{12}$ can also be rejected: F-statistic of 3.923 and P-value of 0.004. It appears that there is a significant relationship between the tertiary qualification registered for and the environmental awareness skills level of graduates $\left(\mathrm{H}_{12}\right.$ accepted $)$. The last null hypotheses $\mathrm{H}_{13}$ is also rejected at the significance level of 0.01 , indicating that there is a highly significant relationship between graduates perception that their tertiary qualification equip them with the necessary generic skills and their level of environmental awareness skills $\left(\mathrm{H}_{13}\right.$ accepted).

Further post-hoc tests (e.g. Scheffé's test) were conducted, but not reported, as this is an exploratory study.

\section{6}

\section{Conclusions and recommendations}

It appears that the current understanding of the relationship between higher education and careers in industry is mainly framed in terms of "transferable skills". Such skills are more generic in nature and not specific to any particular subject-discipline or occupation. As education and training do not cease at the end of one's academic curriculum, there should be a continuous development and refinement of transferable or generic skills. There is a need for graduates to demonstrate employment-related skills and disciplinary expertise, as well as being confident in their understanding and articulation of their capacity development and preparedness for a challenging and dynamic future. As mentioned in the literature review, although not the focus of this article, there is a gap between the skills levels of graduate job seekers and the skills levels expected by employers. Graduates therefore need to find alternative means of acquiring the skills required for their chosen career. In developing these generic skills, a wide range of stakeholders should be involved: students themselves, higher education institutions, employers and policy makers. All these role players should identify a set of valued generic skills that could be effectively assessed at university entry and exit level. It was further highlighted that graduate skills have become increasingly important over the last decade because graduates are entering a more flexible, insecure and technology-dependent workplace than ever before.

For the purposes of analysis and the focus of this article, the following seven graduate generic skills were identified: basic, communication, management, intellectual, self and career management, interpersonal and environmental awareness skills. These generic skills were empirically tested. The following conclusions and recommendations can be made, based on the analysis of variance between the independent variables (classification data) and dependent variables (generic skills factors):

- There appears to be a significant relationship between the tertiary qualification registered for and the basic, self and career management-, interpersonal- and environmental awareness skills level of graduates $\left(\mathrm{HO}_{1} \mathrm{HO}_{8}, \mathrm{HO}_{11}\right.$ and $\mathrm{H}_{12}$ rejected $)$. Differences exist between students holding a BA, BCom, BSc and BTech degree and their respective levels of generic skills mentioned above. Different tertiary qualifications lead to the development of different generic skills levels. Curriculum designers and developers of course content need to ensure that provision is made for the inclusion of developing these generic skills throughout the student's years of study. It could be advisable to develop disciplinerelated generic skills.

- Students previously employed full-time differ regarding their basic skills levels, as compared to students not previously employed full-time ( $\mathrm{H}_{2}$ rejected). Industry experience exposes students to realities of the labour market, forcing them to equip themselves with these basic skills, especially information technology skills. It might be an option for curriculum and course designers to consider the inclusion of a practical component (internship), not merely pure course work, as this may enhance basic and other generic skills.

- Highly significant relationships were found between graduates' orientation towards upgrading skills and their acquired levels 
of basic and intellectual skills $\left(\mathrm{H}_{3}\right.$ and $\mathrm{H}_{7}$ rejected). Differences in orientation towards upgrading skills (ranging from taking self-control for skills development to not being interested in learning new skills) give rise to different basic and intellectual skills levels of graduates. Students need to be orientated and guided by lecturers and student and career councillors, in taking control of their own lifelong skills development and learning without having to be directed or instructed to do so.

- The age level of graduates showed significant relationship with the level of communication skills $\left(\mathrm{H}_{4}\right.$ rejected $)$. Graduates with different age levels do not have the same level of communication skills. It thus appears that "older" students have better communication skills in terms of negotiation, presentation and conflict resolution. This may be a result of various factors such as experience, labour market exposure and realisation of potential. Course content and practical or tutorial sessions should focus on developing these communication skills of students.

- The extent to which graduates perceive their tertiary qualification as equipping them with the necessary generic skills indicated highly significant differences with the level of management, intellectual, self and career management and environmental awareness skills levels $\left(\mathrm{HO}_{5}, \mathrm{H}_{6}, \mathrm{H}_{9}\right.$ and $\mathrm{H} 0_{13}$ rejected). It appears that graduates do not perceive their degrees as having played a major role in developing these generic skills. Levels of basic, communication and interpersonal skills, however, are not related to the extent to which graduates perceive their degrees to have equipped them with generic skills. Curricula should therefore focus more on enhancing the management, intellectual, self and career management and environmental awareness skills levels of graduates, as some of them believe their degrees are not doing this.

- Graduates' gender showed significant relationship with their interpersonal skills level $\left(\mathrm{H}_{10}\right.$ rejected). Male and female graduates differ in their acquired levels of interpersonal skills. Gender differences exist in the acquisition and use of team work, assertiveness, political and networking skills. Developing these skills requires gender-sensitive approaches and techniques.

Figure 2 provides an overview of a generic skills inventory for graduates, indicating what skills should be included and developed by curriculum. This checklist could be used by curriculum and course designers to ensure that these skills are built into courses and degrees in a coordinated effort.

This section concludes with a few general guidelines and recommendations for developing generic skills among graduates:

- Education and training do not come to a halt at the end of the academic course - there should be a lifelong continuous development and refinement of generic skills.

- Graduates need to be equipped with skills that will enable them to maximise their potential for a successful career, by taking ownership of their employability skills to capitalise on life-long career opportunities.

- As a result of a gap between the skills levels of graduate job seekers and the skills levels expected by employers, graduates need to look at alternative means of gaining the skills necessary for their chosen career. This is aggravated by the fact that few organisations provide graduate training programmes this is something that organisations should consider to fill the gap between actual skills level and employer expectations.

- Skills development should take place within an overall framework that provides for the coordination and progression of skills development from each year of study to the next including it not only as individual parts of curricula or by integrating it with academic content.

- All stakeholders, including students, higher education institutions, employers and policy makers, should take joint responsibility for 
developing graduate's generic skills that should be effectively assessed at university entry and exit level.

- Design of new tertiary educational programmes must be guided by focussing on graduate skills as required by industry. To further enhance the interaction between industry and education, both sectors should consider developing more programmes to enable the part-time or temporary transfer of staff between industry and higher education.
- Career advisory services in tertiary institutions should play an important role in raising graduates' preparedness for the world of work, focussing on the generic skills required by industry.

- Course designers should specifically focus on developing interpersonal skills (political skills), management skills (administration) and communication skills (conflict resolution and presentation skills).

Figure 2

A generic skills inventory checklist

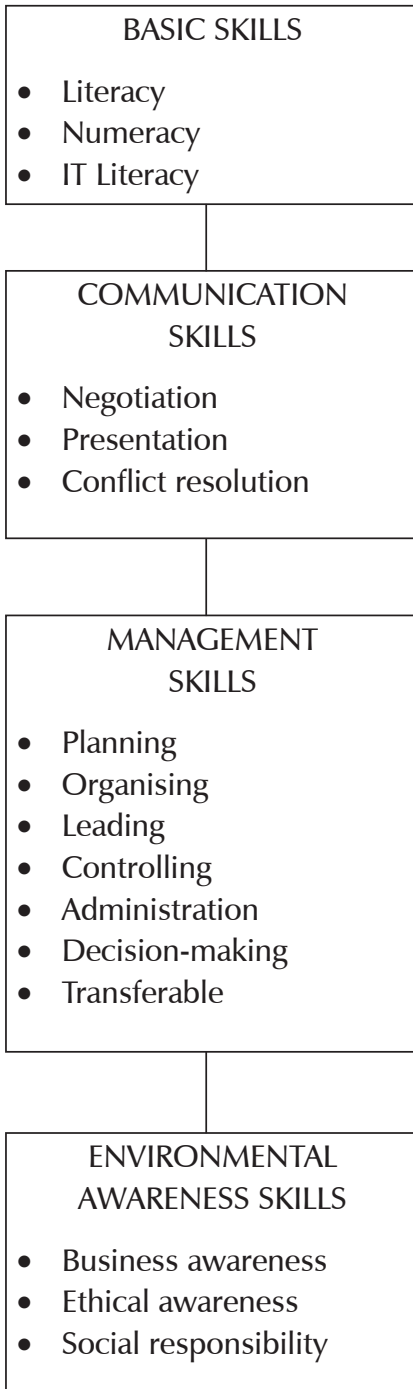
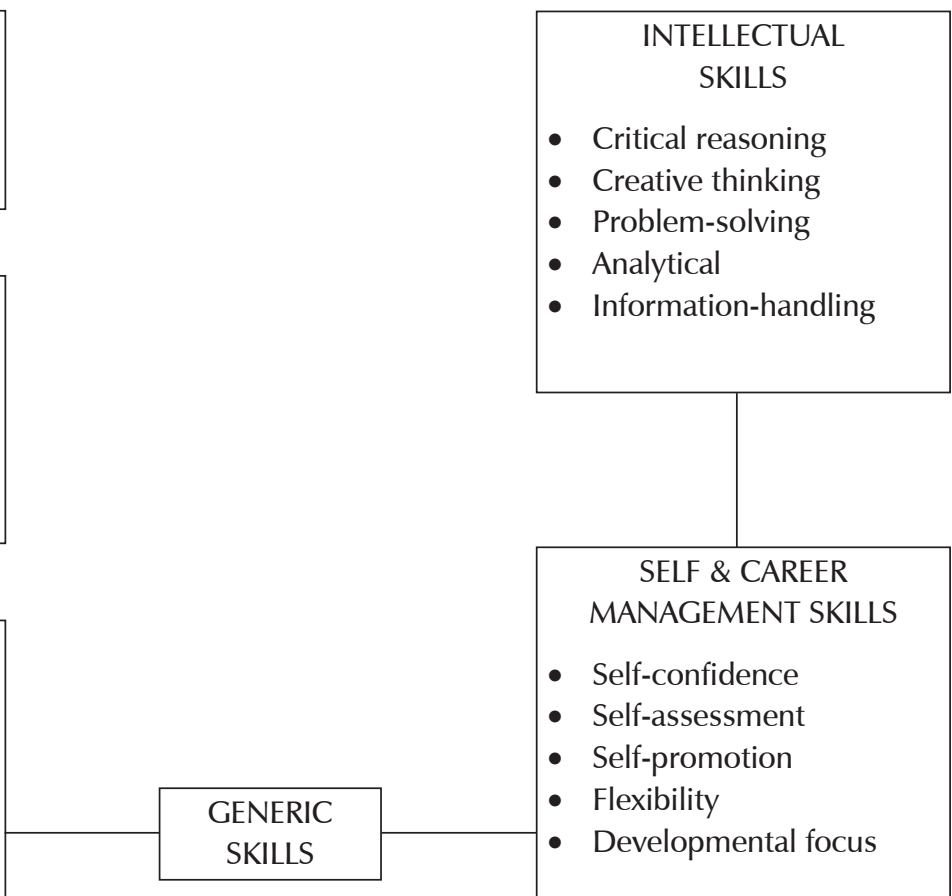

SELF \& CAREER MANAGEMENT SKILLS

- Self-confidence

- Self-assessment

- Self-promotion

- Flexibility

- Developmental focus 
The following extract by La Valle, O'Regan and Jackson (2000) is appropriate as a conclusion of this article:

"There is a growing recognition of the need to enhance graduates' employability for them to find suitable jobs in an increasingly diverse and competitive labour market. The 'employability' debate has centred on the adequacy of the skills graduates develop during their courses. There is growing consensus that it is no longer sufficient for graduates to possess traditional academic and subject specific skills. Nowadays graduates need to develop a range of interpersonal and transferable skills to be able to adapt to changing market circumstances and organisational needs."

\section{List of sources}

1 AMERICAN LIBRARY ASSOCIATION (2006) "Information literacy for faculty and administration", [http://www.ala.org/ala/acrl]. Accessed 7 March 2006

2 ANSWERS.COM (2006) “Administration”, [http:// www.answer.com/topic/ administration]. Accessed 8 March 2006.

3 ARCIONI, E. (1997) "Generic skills: A student perspective", [http://www.cedir.uow.edu.au]. Accessed 31 January 2006.

4 BISHOP, K.N.; REID, A.D.; STABLES, A.; LENCASTRE, M.; STOER, S. \& SOETAERT,

R. (2000) "Developing environmental awareness through literature and media education", Canadian Journal of Environmental Education, 5: 268-286.

5 CHARTERED MANAGEMENT INSTITUTE (2006) "Graduate key skills and employability", [http://www.managers.org.uk]. Accessed 7 March 2006.

6 CLIFF, A.F. (2007) "Assessing the academic literacy skills of entry-level students, using the placement test in English for educational purposes", [http://www.ched.uct.ac.za/seminars]. Accessed 19 November 2007.

7 CONNOR, H.; HIRSCH, W. \& BARBER, L. (2003) "Your graduates and you: Effective strategies for graduate recruitment and development”, IES Report 400. UK: Institute for employment studies.

8 CREBERT, G. (2006) "Graduate skills overview", [http://www.gu.edu.au/centre]. Accessed 31 January 2006.
9 EARL, N. (2006) "Over half of graduate job seekers yet to find graduate-level employment", [http://www.manpower.co.uk/news/graduate]. Accessed 31 January 2006.

10 EIRONLINE (2006) "The changing meaning of skill and its implications for UK vocational education and training policy", [http://www.eiro. eurofound.eu.int]. Accessed 2 March 2006.

11 EISENBERG, M.B. \& JOHNSON, D. (2006) "Teaching information literacy: The big six skills approach to information problem solving", [http:// www.itrc.ucf.edu/webcamp]. Accessed 7 March 2006.

12 FIELDING, M. (2003) Effective Communication in Organizations: Preparing Messages that Communicate ( $2^{\text {nd }}$ ed.) Juta: Cape Town.

13 FRAME, I. \& CANTER, M. (2001) "A menu of graduate skills - The specification of degree level skills for construction and surveying students", Paper delivered at COBRA Conference. Caledonian University: Glasgow.

14 FORSTER, M. (2006) "Graduate skills assessment”, [http://www.murdoch.edu.au/eddev]. Accessed 7 March 2006.

15 GIBSON, J.L., IVANCEVICH, J.M. \& DONELLY, J.H. (1997) Organizations: Behaviour, Structure, Processes ( $9^{\text {th }}$ ed.) Irwin: Chicago.

16 GOLDFINCH, J. \& HUGHES, M. (2007) "Skills, learning styles and success of first year undergraduates", Active learning in Higher Education, 8(3): 259-273.

17 GRADUATE SKILLS ONLINE (2006) "Key skills", [http://www.careers.rdg.ac.uk]. Accessed 31 January 2006.

18 GREEN, F. \& DICKERSON, A.P. (2002) The Growth and Valuation of Generic Skills. Studies in Economies 0203. University of Kent.

19 HAIR, J.F.; ANDERSON, R.E.; TATHAM, R.L. \& BLACK, W.C. (1998) Multivariate Data Analysis, Prentice Hall, Inc: New Jersey.

20 HELLRIEGEL, D.; JACKSON, S.E.; SLOCUM, J.; STAUDE, G.; AMOS, T.; KLOPPER, H.B.; LOUW, L. \& OOSTHUIZEN, T. (2004) Management ( $2^{\text {nd }} \mathrm{SA}$ ed.) Oxford University Press: Cape Town.

21 HILlAGE, J. \& POLLARD, E. (1998) Employability: Developing a Framework for Policy Analysis, DfEE: London.

22 HOLMES, L. (2000) "Reframing the skills agenda in higher education: Graduate identity and the double warrant", Paper delivered at The future business of higher education conference. Oxford. March 2000.

23 KAIJAGE, E.S. (2006) "Knowledge and skills of B.Com graduates of the faculty of commerce and 
management, University of Dar es Salaam in the job market”, [http://www.aau.org/studyprogram]. Accessed 31 January 2006.

24 KELLY, R. (2006) "Graduate skills: What employers want?”, [http://www.graduatecareers. com]. Accessed 7 March 2006.

25 KINGS COLLEGE LONDON (2006) [http://www. kcl.ac.uk/gshs/gsdp/development]. Accessed 31 January 2006.

26 LA VALLE, I.; O'REGAN, S. \& JACKSON, C. (2000) "The art of getting started: Graduate skills in a fragmented labour market", IES Report 364. Institute for employment studies: UK

27 MAHER, A. \& NIELD, K. (2005) "Enhancing student employability: Higher education and workforce development", Paper delivered at Ninth Quality in Higher Education International Seminar, Birmington. 27-28 January 2005.

28 MANNIX, E. \& NEALE, M.A. (2007)

"Diverse teams in organizations", [http://www. psychologicalscience.org]. Accessed 19 November 2007.

29 MARWALA, T. (2006) "Skills necessary for the advancement of South Africa, Umrabulo, 26, August 2006", [http://www.anc.org.za/ancdocs/]. Accessed 14 February 2007.

30 MCNAIR, S. (2003) Employability in Higher Education, LTSN Generic Centre, University of Surrey: Surrey.

31 MOONEY, D. (2002) "Leadership skills: Leader or manager? Which are you? Which should you be?" Communicator, 3 (2): 1-5.

32 MULLINS, L.J. (1996) Management and Organisational Behaviour ( $4^{\text {th }}$ ed.) Pitman: London.
33 NATIONAL CENTRE FOR VOCATIONAL EDUCATION RESEARCH (2003) At a Glance, Australian Training Authority: Adelaide.

34 NIEMAN, G. \& BENNETT, A. (2004) Business Management: A Value Chain Approach, Van Schaik: Pretoria.

35 QUEENSLAND UNIVERSITY OF TECHNOLOGY (2005) "Graduate capabilities", [http://www.qut.edu.au/admin/mop]. Accessed 18 April 2005.

36 ROBBINS, S.P. \& DECENZO, D.A. (2004) Supervision Today! (4 $4^{\text {th }}$ ed.) Pearson: New Jersey.

37 SAICA (2006) "Technical and professional skill requirements, March 2006", [http://www. saica. co.za]. Accessed 14 February 2007.

38 SCHERMERHORN, J.R.; HUNT, J.G. \& OSBORN, R.N. (1997) Organisational Behaviour $\left(6^{\text {th }}\right.$ ed.) John Wiley: New York.

39 UCE. (2006) "Graduate's work: A guide to future employment”, [http://www.uce.ac.uk/crq/ publications]. Accessed 31 January 2006.

40 UK CENTRE FOR LEGAL EDUCATION (1998) "General transferable skills: Intellectual skills”, [http://www.ukcle.ac.uk/resources/]. Accessed 26 April 2006.

41 UNIVERSITY OF HERTFORDSHIRE (2005) "Mapping and tracking graduate skills", [http:/ www.herts.ac.uk/envstrat/HILP]. Accessed 18 April 2005.

42 WOODBURY UNIVERSITY (2006) "Skills for graduates in the $21^{\text {st }}$ century", [http://www. woodbury.edu]. Accessed 31 January 2006.

43 WORDNET (2006) "WordNet search", [http:// www.wordnet.princeton.edu]. Accessed 2 March 2006. 